\title{
Correction to: Schoolin' Black Girls: Politicized Caring and Healing as Pedagogical Love
}

\author{
Sherell A. McArthur ${ }^{1} \cdot$ Monique Lane $^{2}$
}

Published online: 9 April 2019

(c) Springer Nature B.V. 2019

\section{Correction to: The Urban Review (2019) 51:65-80 https://doi.org/10.1007/s11256-018-0487-4}

The original version of this article unfortunately contained some errors in the text.

In Introduction section, the following text needs to be removed as this is an inaccurate statistic.

The National Center for Education Statistics reports for the 2013-2014 academic year that $66 \%$ of associate and $64 \%$ of bachelor's degrees are awarded to Black women by degree-granting institutions, outnumbering Black men, and men and women of other races (2017).

In sentence 'Drawing from her experiences as a high school teacher, Monique discusses...', 'Monique' should be 'the author'.

The casing of two phrases 'Feminist Pedagogy' and 'Feminist Praxis' should be in lower case.

The casing of author name 'Hooks' needs to be in lower case.

Under section 'A Politicized Ethic of Care and Fo-Real Love', in sentence 'The 2-years investigation of the framework...', '2-years' should be '2-year'.

In sentence 'In the discussion that follows, Author 1 highlights...', 'Author 1' should be 'Author 2'.

Under section 'Fo-real Love', the footnote should denote 'King High school' in the sentence 'Through an analysis of Black feminist curricula...'

The page number at the end of the sentence 'One drawback of pedagogies devoid of an emotional...' needs to be removed.

The original article can be found online at https://doi.org/10.1007/s11256-018-0487-4.

Sherell A. McArthur

Sherell.McArthur@uga.edu

Monique Lane

ml15@stmarys-ca.edu

1 University of Georgia, 110 Carlton Street, Athens, GA 30602, USA

2 Saint Mary's College of California, 1928 Saint Mary’s Road, Moraga, CA 94575, USA 
In section 'Space and Place for Healing', '14 weeks' should be '14-week' and the citation McArthur (2019) should be McArthur (2018) and its correct reference is as follows:

McArthur, S.A. (2018). “My Sister, Myself”: Why the Miseducation of Black girls requires spaces and places for their healing." In M.B. Sankofa Waters, V.E. Evans-Winters, and B.L. Love (Eds.) Celebrating Twenty Years of Black Girlhood: Lauryn Hill Reader (pp. 101-111). New York, NY: Peter Lang Publishing.

In paragraph that starts 'At the beginning of each Beyond Your Perception...', 'Author 1' should be 'I' in two instances.

In section 'Pedagogy of Love: Implications for Classroom Practice', italics need to be removed for the phrase 'politicized ethic of care'.

Publisher's Note Springer Nature remains neutral with regard to jurisdictional claims in published maps and institutional affiliations. 